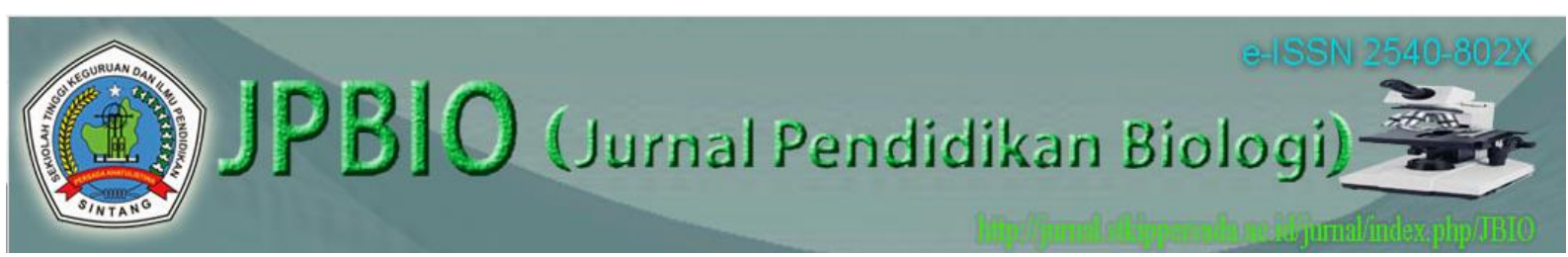

JPBIO (Jurnal Pendidikan Biologi)

Vol. 2 No. 2 November 2017 | 27 - 33

ISSN 2540-802x (Online)

DOI: http://dx.doi.org/10.31932/ JPBIO (Jurnal Pendidikan Biologi)

http://jurnal.stkippersada.ac.id/jurnal/index.php/JBIO

\title{
PENGARUH MODEL READING QUESTIONING ANSWERING (RQA) TERHADAP PENGETAHUAN METAKOGITIF SISWA PADA MATERI SISTEM PERNAPASAN MANUSIA
}

\author{
Defvia Ayu Lashari ${ }^{1}$, Yasinta Lisa ${ }^{2^{*}}$, Hendrikus Julung ${ }^{3}$ \\ ${ }^{1}$ Mahasiswa Program Studi Pendidikan Biologi, STKIP Persada Khatulistiwa Sintang \\ ${ }^{2,3}$ Dosen Program Studi Pendidikan Biologi, STKIP Persada Khatulistiwa Sintang \\ E-mail: defvia02@gmail.com,yasintalisa@gmail.com*,henjulung@gmail.com
}

Diterima: 20 Mei $2017 \quad$ Direvisi: 17 Juni $2017 \quad$ Disetujui: 28 Oktober 2017

\begin{abstract}
ABSTRAK
Tujuan penelitian ini adalah untuk mengetahui pengaruh model pembelajaran Reading, Questioning, and Answering (RQA) terhadap kemampuan metakognitif siswa Kelas VIII SMP Negeri 6 Satu Atap Sintang pada materi Sistem pernapasan manusia. Variabel pada penelitian ini ada dua yaitu variabel bebas "model pembelajaran Reading Questioning Answering (RQA)" dan variabel terikat "kemampuan Metakognitif". Metode yang digunakan dalam penelitian ini adalah metode kuantitatif. Bentuk penelitian yang digunakan yaitu Quasieksperimen dengan desain penelitian Nonequivalent Control Group Design. Teknik pengambilan sampelnya menggunakan teknik Sampling Purposive. Teknik pengumpulan data menggunakan teknik observasi langsung, teknik pengukuran, dan teknik komunikasi tidak langsung. Alat pengumpulan data yang digunakan adalah lembar observasi, soal tes, dan angket. Hasil analisis data observasi guru di kelas eksperimen dan kelas kontrol dengan persentase $100 \%$, berkriteria sangat baik, sedangkan data observasi siswa pada kelas eksperimen dengan persentase rata-rata $100 \%$ berkriteria sangat baik. Berdasarkan perhitungan kemampuan metakognitif siswa diperoleh nilai rata-rata pretest 39,00 untuk kelas eksperimen dan 48,32 untuk kelas kontrol serta nilai rata-rata posttest 79,68 untuk kelas eksperimen dan 64,04 untuk kelas kontrol. Analisis data menggunakan program SPSS Statistics 20 dengan jumlah siswa 28 orang kelas eksperimen dan 28 orang kelas kontrol diperoleh hasil pretest dan posttest berdistribusi normal dan homogen. Sedangkan pada hasil uji hipotesis posttest diketahui bahwa nilai sig. (2-tailed) adalah 0,000 dengan nilai $\alpha=$ 0,05 . Hal ini berarti nilai sig. (2-tailed) $<\alpha(0,000<0,05)$ maka H1 diterima. Disimpulkan bahwa terdapat perbedaan yang signifikan kemampuan metakognitif siswa antara kelas eksperimen dan kelas kontrol di kelas VIII SMP Negeri 6 Satu Atap Sintang pada materi sistem pernapasan manusia. Hasil angket respon siswa dengan rata-rata $88,20 \%$ (sangat kuat).
\end{abstract}

Kata Kunci: reading questioning answering $(R Q A)$, kemampuan metakognitif

ABSTRACT

The purpose of this study was to determine the Influence of Reading Questioning Answering (RQA) to metacognitive of ability Class VIII Junior High School 6 SatuAtapSintang In the Matter of Human Respiratory System. the variables in this study there are two independent 
variables "learning model Reading Questioning Answering (RQA)" the dependent variable "ability of metacognitive". The method used in this research is quantitative method. Research form used is quasi-experimental research design nonequivalent control group design. The technique of taking the sample using purposive sampling techniques Data collection techniques using direct observation techniques, measurement techniques, and techniques of indirect communication. Data collection tools used were observation sheet, test questions, and questionnaires. The results of data analysis in the experimental class teacher observation and control classes with a percentage of $100 \%$, very good criteria, Based on the students' metacognitive ability calculation, the average value of pretest 39,00 for experiment class and 48,32 for control class and posttest mean value 79,68 for experiment class and 64,04 for control class. Data analysis using SPSS Statistics 20 program with the number of students of 28 experimental class and 28 control class obtained pretest and posttest result of normal and homogenous distribution. While on result of hypothesis test posttest known that value of sig. (2-tailed) is 0,000 with $\alpha=0.05$. This means the sig value. (2-tailed) $<\alpha(0,000<$ 0.05) then $\mathrm{H} 1$ is accepted. It was concluded that there was a significant difference of students' metacognitive ability between the experimental class and control class in Grade VIII SMP Negeri 6 SatuAtapSintang on the material of the human respiratory system. Result of questionnaire of student response with average $88,20 \%$ (very strong).

Keywords: reading questioning answering $(R Q A)$, ability of metacognitive

\section{PENDAHULUAN}

Pendidikan merupakan perwujudan dari salah satu tujuan pembangunan nasional Indonesia, yakni ingin mencerdaskan kehidupan bangsa. Saat ini bidang pendidikan merupakan salah satu bidang pembangunan yang mendapat perhatian serius dari pemerintah. Pemahaman terhadap tujuan pendidikan akan tercermin bahwa pendidikan merupakan faktor yang sangat strategis sebagai dasar pembangunan bangsa.Sejalan dengan itu, apabila dihubungkan dengan eksistensi dan hakikat hidup manusia, kegiatan pendidikan diarahkan pada manusia sebagai makhluk individu, sosial, dan religius.

Memasuki satu dasawarsa abad ke-21, keadaan SDM Indonesia masih belum kompetitif, yaitu belum mampu bersaing di dunia internasional. Menurut Hasanuddin (2012: 19) komponen utama yang mempengaruhi daya saing tersebut, yaitu: makroekonomi, kesehatan, dan pendidikan dasar, serta pendidikan tinggi dan pelatihan. Masyarakat gemar membaca merupakan persyaratan terwujudnya masyarakat gemar belajar yang menjadi salah satu ciri masyarakat maju dan beradab. Budaya membaca di masyarakat Indonesia, tak terkecuali di kalangan pelajar dan anak-anak, masih jauh dari harapan. Menurut Pertiwi dan Sugianto (2006: 152), berdasarkan data UNESCO tahun 2004, angka "melek huruf" di Indonesia adalah $89 \%$. Pada kawasan Asia Tenggara, Indonesia berada di bawah Malaysia $(89,4 \%)$, Brunei Darussalam $(92,3 \%)$, Singapura (93,5\%), Vietnam $(94,2 \%)$, Filipina $(96,1 \%)$, dan Thailand $(96,2 \%)$. Indonesia hanya berada di atas Kamboja $(70,6 \%)$, Laos $(64,8 \%)$, Myanmar (85,9\%), dan Timor Leste (43\%). Negara Jepang yang merupakan salah satu negara paling maju dalam bidang ilmu pengetahuan memiliki angka melek huruf $99 \%$. Lebih dari 90\% negara-negara di Eropa memiliki angka melek huruf diatas 97\%. Hal ini mengindikasikan bahwa semakin tinggi tingkat melek huruf sebuah negara, semakin tinggi tingkat perkembangan negara tersebut.

Sadar akan hasil-hasil pendidikan yang belum memadai, maka banyak upaya perbaikan yang telah dilakukan oleh pemerintah. Upaya-upaya tersebut telah dilakukan secara intensif, tetapi pengemasan pendidikan sering tidak sejalan dengan hakikat belajar dan pembelajaran, dengan kata lain, reformasi pendidikan yang dilakukan pemerintah masih belum seutuhnya memperhatikan konsepsi belajar dan pembelajaran. Hal lain yang menjadi dasar rendahnya kualitas hasil belajar tersebut yaitu dikarenakan siswa malas dalam membaca. Seringkali kita mendengar istilah membaca merupakan jembatan ilmudan bangsa yang cerdas adalah bangsa yang gemar membaca oleh sebab itu mengapa membaca sangat penting. Menurut Haerullah dan Usman (2013: 181), penggunaan strategi, model atau 
pola pembelajaran merupakan aspek utama dalam proses pendidikan di Sekolah. Pengalaman belajar yang dihayati oleh siswa selama pembelajaran berlangsung akan sangat berperan dalam pembentukan kemampuan dan kualitas dari pembelajaran tersebut. Kualitas pembelajaran merupakan salah satu unsur dari paradigma baru pengelolaan pendidikan. Oleh karena itu, guru memiliki tanggung jawab yang besar dalam membentuk pengalaman belajar siswa.

Berdasarkan hasil observasi di Sekolah Menengah Pertama Negeri 6 Satu Atap Sintang dari tanggal 23 Februari s/d 01 Maret 2017, diperoleh dari hasil angket bahwa minat baca siswa di kelas VII pada Sekolah Menengah Pertama Negeri 6 Satu Atap Sintang yaitu sebesar $38,81 \%$ dengan kategori rendah. Disisi lain berdasarkan observasi ditemukan bahwa siswa belum mengetahui bagaimana untuk belajar, apa pentingnya belajar, bagaimana mengetahui kemampuan belajar yang dimiliki dan mengetahui strategi belajar terbaik untuk belajar efektif. Kurangnya pengetahuan metakognitif siswa tersebut, sehingga ini juga berdampak pada pembelajaran IPA dimana masih ada siswa yang kurang mampu menguasai materi pembelajaran, hal ini terlihat dengan rendahnya kemampuan metakognitif siswa yang tidak mencapai Kriteria Ketuntasan Minimal (KKM) yang ditetapkan oleh Sekolah Menengah Pertama Negeri 6 Satu Atap Sintang untuk mata pelajaran IPA yaitu 75. Berdasarkan nilai rata-rata ulangan harian pada materi Sistem Pernapasan di kelas VIII Sekolah Menengah Pertama Negeri 6 Satu Atap Sintang tahun pelajaran 2016/2017 terdapat $77,5 \%$ siswa belum tuntas dengan rata-rata nilai yaitu sebesar 64,5 .

Hal ini menunjukkan bahwa tingkat kesadaran dan kemandirian dalam mengikuti pembelajaran, siswa tersebut masih tergolong rendah. Kesadaran ini sangat menentukan seorang siswa dalam merencanakan tugas, memonitor proses belajarnya, serta mengevaluasi hasil belajarnya, dimana ini merupakan komponen dari pengetahuan metakognitif.

Menurut Imel (Brasilita dkk, 2013: 181), mengatakan siswa yang menggunakan pengetahuan atau kemampuan metakognitif memiliki prestasi yang lebih baik karena pengetahuan atau kemampuan metakognitif memungkinkan siswa untuk melakukan perencanaan, mengikuti perkembangan, dan memonitor proses belajarnya. Menurut Corebima 2009 (Haerullah dan Usman, 2013: 181), mengatakan RQA merupakan model yang baru dikembangkan berdasar kenyataan bahwa hampir semua siswa yang ditugaskan membaca materi belajar terkait pembelajaran yang akan datang selalu tidak membaca. Akibatnya model pembelajaran yang dirancang sulit atau tidak terlaksana, dan pada akhirnya pemahaman terhadap materi pembelajaran menjadi rendah atau bahkan sangat rendah. Implementasi model pembelajaran $R Q A$ terbukti mampu memaksa para siswa untuk membaca materi yang ditugaskan, sehingga model pembelajaran yang dirancang dapat terlaksana dan pemahaman terhadap materi pembelajaran berhasil ditingkatkan hampir $100 \%$.

$R Q A$ dianggap suatu model pembelajaran yang berlandaskan pada teori pembelajaran konstruktivisme. Menurut Haerullah dan Usman (2013: 181) mengatakan strategi pembelajaran RQA, siswa ditugaskan membaca materi tertentu. Selanjutnya, atas dasar pemahaman terhadap bacaan itu, siswa diminta membuat pertanyaan secara tertulis dan menjawabanya sendiri. Substansi yang ditanyakan adalah yang penting atau sangat penting terkait dengan materi bacaan, sedangkan jumlah pertanyaan disesuaikan dengan keadaan. Pertanyaan dan jawaban yang dibuat secara kelompok, dipresentasikan dan ditanggapi oleh siswa lain. Model pembelajaran Reading, Questioning and Answering (RQA) dapat membantu memberdayakan pengetahuan metakognitif siswa yang mengarah pada kemampuan siswa untuk dapat memonitor belajar siswa itu sendiri, manjadi manajer atas diri sendiri serta menjadi penilai atas pemikiran dan pembelajaran sendiri dengan tahapantahapan model pembelajaran Reading, Questioning and Answering (RQA) yaitu reading (membaca), questioning (bertanya) dan answering (menjawab). Selanjutnya menurut Pierce (Fauzi, 2013: 23), mengatakan bahwa meringkas tidak hanya akan meningkatkan pemahaman siswa, tetapi juga akan membantu mereka memonitor pemahamannya.

Kemampuan metakognitif untuk memonitor hasil belajar siswa sendiri dengan menggunakan model-model tertentu, agar belajar dan mengingat dapat berkembang. 
Mengidentifikasi ide-ide penting dengan menggaris bawahi atau menemukan kata kunci pada bahan bacaan, kemudian merangkai menjadi satu kalimat, meramalkan hasil, membuat daftar pertanyaan dari bahan bacaan kemudian menjawabnya sendiri, membedakan antara hal yang subtansial dan tidak subtansial dari bahanbacaan, membedakan memutuskan bagaimana menggunakan waktu dan mengulang informasi merupakan beberapa bentuk strategi keterampilan berpikir tingkat tinggi, sehingga kelebihan model pembelajaran Reading, Questioning and Answering (RQA) dapat diketahui.

\section{METODE PENELITIAN}

Metode yang digunakan dalam penelitian ini adalah metode kuantitatif. Bentuk penelitian yang digunakan yaitu Quasi-eksperimen dengan desain penelitian Nonequivalent Control Group Design. Teknik pengambilan sampelnya menggunakan teknik Purposive Sampling. Teknik pengumpulan data menggunakan teknik observasi langsung, teknik pengukuran, dan teknik komunikasi tidak langsung. Pengumpulan data menggunakan beberapa instrument yaitu: (a) LKS, (b) lembar observasi, (c) angket respon siswa, (d) soal tes.Populasi dalam penelitian ini adalah seluruh siswa kelas VIII SMP Negeri 6 Satu Atap sintang. Sampel dalam penelitianini di ambil dua kelas VIII, SMP Negeri 6 Satu Atap Sintang yaitu pada kelas VIII A dan kelas VIII B. Berdasarkan hasil observasi jumlah siswa pada kelas eksperimen yaitu kelas VIII A dengan jumlah siswa 28, sedangkan kelas kontrol yaitu VIII B dengan jumlah siswa sebanyak 28 siswa.

Prosedur pada penelitian ini terdiri dari beberapa tahapan berikut ini adalah proses tahapan yang dilakukan :

1. Tahap persiapan : penentuan populasi dan sampel, serta persiapan pembuatan perangkat pembeljaran (RPP, bahan ajar), dan instrumen penelitian.

2. Tahap pre-test: dilakukan tes awal untuk mengetahui pengetahuan awal siswa kelas VIII A (kelas eksperimen) yang berjumlah 28 siswa, dan pada kelas VIII B (kelas kontrol) yang berjumlah 28 siswa.

3. Tahap pelaksanaan : dilakukan kegiatan pembelajaran menggunakan strategi $R Q A$ (Reading, Questioning, and Answering) di kelas eksperimen dan pada kelas kontrol tidak diberikan perlakuan.

4. Tahap post-test : dilakukan tes akhir untuk mengetahui akhir belajar siswa pada kelas perlakuan dan kelas kontrol.

5. Tahap analisis data : Analisis data dilakukan dengan menggunakan analisis SPSS Statistic 20 antara hasil pretest dan post-test pada kelas eksperimen dan kontrol.

6. Tahap uji hipotesis : dilakukan penarikan kesimpulan untuk menolak atau menerima hipotesis berdasarkan hasil hasil pre-test dan pos-test kelas eksperimen dan kontrol.

7. Tahap penarikan kesimpulan: setelah hipotesis penelitian diuji, selanjutnya dilakukan penarikan kesimpulan.

Perangkat pembelajaran dalam penelitian ini terdiri atas: Silabus dan Rencana Pelaksanaan Pembelajaran (RPP). RPP dan Silabus dikembangkan dan disesuaikan dengan model pembelajaran $R Q A$. Komponen-komponen yang ada dalam silabus meliputi; standar kompetensi, kompetensi dasar, materi pokok, kegiatan belajar, indikator, penilaian, alokasi waktu, serta alat/bahan dan sumber belajar. Analisis data menggunakan SPSS meliputi (a) uji normalitas, (b) uji homogenitas, (c) uji hipotesis. Pengkatagorian kemampuan metakognitif siswa merujuk pada Haerullah dan Usman (2013: 182) dapat dilihat pada Tabel 1 berikut:

Tabel 1 Pengkatagorian Kemampuan Metakognitif

\begin{tabular}{cc}
\hline Rentan Skor & Katagori \\
\hline $0-20$ & Sangat Beresiko \\
$21-40$ & Belum Berkembang \\
$41-60$ & Mulai Berkembang \\
$61-80$ & Berkembang Baik \\
$81-100$ & Sangat Baik \\
\hline
\end{tabular}




\section{HASIL DAN PEMBAHASAN}

Data yang diperoleh dan dianalisis dalam penelitian ini digunakan untuk menjawab masalah penelitian. Data yang diperoleh terdiri dari : pretest dan posttest pengetahuan metakognitif siswa pada materi sistem pernapasan manusia. Pengolahan data yang diperoleh dilakukan dengan menggunakan Manual dan SPSS Statistic 20.

Hasil validasi instrument yang dilakukan oleh validator ahli diperoleh analisis hasil validasi silabus tingkat pencapaian $97,6 \%$ dengan kualifikasi "Sangat layak dan tidak perlu direvisi", analisis hasil validasi RPP tingkat pencapaian 92,2\% dengan kualifikasi "Sangat layak dan tidak perlu direvisi", analisis hasil validasi LKS tingkat pencapaian 92,9\% dengan kualifikasi "Sangat layak dan tidak perlu direvisi", analisis validasi lembar observasi tingkat pencapaian 93,8\% dengan kualifikasi "Sangat layak dan tidak perlu direvisi", analisis validasi angket respon siswa tingkat pencapaian $87,5 \%$ dengan kualifikasi "Sangat layak dan tidak perlu direvisi", dan analisis validasi soal tes tingkat pencapaian $97,3 \%$ dengan kualifikasi "Sangat layak dan tidak perlu direvisi".

Hasil observasi guru yang dilakukan pada pertemuan pertama dan kedua diperoleh jawaban "Ya" sebanyak 13 jawaban jika dipersentasekan adalah sebesar 100\%. Dari kedua hasil pengamatan pada setiap pertemuan tersebut diperoleh rata-rata yang berada pada rentang $81 \%-100 \%$ sehingga berkreteria sangat baik.

Hasil observasi siswa pada pertemuan pertama dan kedua diperoleh jawaban "Ya" sebanyak 13 jika dipersentasekan adalah sebesar 100\%. Berdasarkan hasil rata-rata akumulasi pertemuan pertama dan kedua menunjukkan kriteria sangat baik, yang artinya siswa melaksanakan pembelajaran dengan sungguh-sungguh.

\section{Hasil Belajar}

Hasil analisis data pretest dan posttest kemampuan metakognitif siswa pada kelas eksperimen dan kelas kontrol dapat dilihat pada Tabel 1 berikut:

Tabel 2 Nilai Kemampuan metakognitif Siswa

\begin{tabular}{ccccc}
\hline \multirow{2}{*}{ Nilai } & \multicolumn{2}{c}{ Kelas Eksperimen } & \multicolumn{2}{c}{ Kelas Kontrol } \\
\cline { 2 - 5 } & Pretest & Posttest & Pretest & Posttest \\
\hline N & 28 & 28 & 28 & 28 \\
Nilai Tertinggi & 61 & 96 & 69 & 83 \\
Nilai Terendah & 19 & 63 & 31 & 48 \\
Nilai Rata-Rata & 39,00 & 79,68 & 41,00 & 64,04 \\
\hline
\end{tabular}

Sumber:Analisis Data Peneliti (2017)

\section{Uji Prasyarat}

Berdasarkan hasil uji normalitas pretest kelas eksperimen menggunakan program SPSS Statistics 20 menyatakan nilai sig. (2-tailed) $>\alpha(0,913>0,05)$ yang artinya sebaran data pretest kelas eksperimen berdistribusi normal. Hasil uji normalitas posttest kelas eksperimen menyatakan nilai sig. (2-tailed) $>\alpha(0,825>0,05)$ yang artinya sebaran data posttest kelas eksperimen berdistribusi normal. Hasil uji normalitas pretest kelas kontrol menyatakan nilai sig. (2-tailed) $>\alpha(0,527>0,05)$ yang artinya sebaran data pretest kelas kontrol berdistribusi normal. Hasil uji normalitas posttest kelas eksperimen menyatakan nilai sig. (2-tailed) $>\alpha(0,932>0,05)$ yang artinya sebaran data posttest kelas kontrol berdistribusi normal. Untuk lebih jelasnya dapat dilihat pada Tabel 2.

Tabel 3 Hasil Uji Normalitas Data

\begin{tabular}{ccccccc}
\hline Kelas & JenisTes & $\bar{x}$ & S & Sig. & $\boldsymbol{\alpha}$ & Ket \\
\hline Kelas & Pretest & 39,00 & 11,34 & 0,913 & 0,05 & Normal \\
eksperimen & Posttest & 79,68 & 8,78 & 0,825 & 0,05 & Normal \\
\hline \multirow{2}{*}{ Kelaskontrol } & Pretest & 41,00 & 8,65 & 0,527 & 0,05 & Normal \\
& Posttest & 64,04 & 10,36 & 0,932 & 0,05 & Normal \\
\hline
\end{tabular}


Tabel 4 Uji Homogenitas pretest dan posttest kelas eksperimen dan kelas kontrol

\begin{tabular}{cccc}
\hline JenisTes & $\begin{array}{c}\text { Sig. (2- } \\
\text { tailed) }\end{array}$ & A & Kesimpulan \\
\hline $\begin{array}{c}\text { Pretest kelas eksperimen dan kelas } \\
\text { control }\end{array}$ & 0,074 & 0,05 & Homogen \\
$\begin{array}{c}\text { Posttest kelas eksperimen dan } \\
\text { kelas control }\end{array}$ & 0,205 & 0,05 & Homogen \\
\hline
\end{tabular}

Sumber:Analisis Data Peneliti (2017)

Berdasarkan hasil uji homogenitas data diperoleh sig. (2-tailed) Untuk Pretest siswa kelas eksperimen dan siswa kelas kontrol sebesar 0,074>0,05 maka data pretest adalah homogen dan pada data posttest sig. (2-tailed) 0,205> 0,05 artinya data posttest homogen. Jadi, dari hasil analisis dengan SPSS statistic 20 tersebut membuktikan bahwa data untuk masing-masing tes semuanya dinyatakan homogen.

Berdasarkan hasil perhitungan menggunakan program SPSS Statistics 20 pada pretets diperoleh nilai Sig. (2-tailed) > a yakni 0,461>0,05 maka $\mathrm{H}_{0}$ diterima dan $\mathrm{H}_{1}$ ditolak, yakni tidak terdapat perbedaan pengetahuan metakognitif siswa antara kelas eksperimen dan kelas kontrol pada pengukuran awal (pretest), sedangkan hasil Posttest kelas eksperimen dan kelas kontrol diperoleh nilaiSig. (2-tailed) $<$ a yakni 0,000 0,05 maka $\mathrm{H}_{0}$ ditolak dan $\mathrm{H}_{1}$ diterima, yakni terdapat perbedaan pengetahuan metakognitif siswa antara kelas eksperimen dan kelas kontrol pada pengukuran akhir (posttest). Hasil uji lebih lengkap dapat dilihat padaTabel 3 berikut.

Tabel 5 Uji Hipotesis pretest dan posttestk elas eksperimen dan kelas kontrol

\begin{tabular}{cccc}
\hline Jenis Tes & $\begin{array}{c}\text { Sig. (2- } \\
\text { tailed) }\end{array}$ & a & Kesimpulan \\
\hline $\begin{array}{c}\text { Pretest kelas eksperimen dan kelas } \\
\text { control }\end{array}$ & 0,461 & 0,05 & Hoditerima $^{-}$ \\
$\begin{array}{c}\text { Posttest kelas eksperimen dan } \\
\text { kelas control }\end{array}$ & 0,000 & 0,05 & Terdapat \\
\hline \multicolumn{2}{c}{ Sumber: Analisis Data Peneliti (2017) }
\end{tabular}

\section{Respon Siswa}

Untuk mengetahui respon siswa terhadap diterapkannya model pembelajaran Reading, Questioning and Answering (RQA) bahwa dari 28 siswa yang mengisi angket respon diperoleh persentasese besar $74,25 \%$ dengan kategori Kuat, hal ini berarti bahwa siswa merespon positif terhadap diterapkannya model Pembelajaran Reading, Questioning and Answering (RQA)Hasil analisis data yang telah diuraikan menunjukan bahwa terdapat perbedaan hasil belajar siswa antara kelas eksperimen dan kelas kontrol yang menggunakan strategi pembelajaran yang berbeda. Pada kelas eksperimen pembelajaran menggunakan model $R Q A$, sedangkan pada kelas kontrol menggunakan pembelajaran konvensional. Siswa pada kelas eksperimen memiliki hasil belajar yang lebih tinggi dibandingkan dengan hasil belajar siswa pada kelas kontrol ini berarti model pembelajaran $R Q A$ berpengaruh terhadap hasil belajar siswa. Berdasarkan hasil tersebut, maka dapat disimpulkan bahwa penggunaan model $R Q A$ dalam proses belajar mengajar dapat meningkatkan hasil belajar dan pengetahuan metakognitif siswa dibandingkan dengan pembelajaran konvensionaL

\section{SIMPULAN}

1. Proses pembelajaran menggunakan model pembelajaran Reading questioning Answering (RQA) di kelas VIII A Sekolah Menengah Pertama Negeri 6 Satu Atap 
Sintang kelas eksperimen berjalan dengan baik. Rata-rata persentase aktivitas guru pertemuan pertama dan kedua sebesar $100 \%$. Rata-rata persentase aktivitas siswa kelas eksperimen sebesar $100 \%$ berkriteria "Baik".

2. Pengetahuan Metakognitif siswa sebelum pembelajaran pada materi sistem pernapasan di kelas eksperimen diperoleh nilai rata-rata 39,00 dengan kategori "Rendah" dan setelah pembelajaran diperoleh nilai rata-rata 79,68 dengan kategori "Tinggi". Sementara pengetahuan metakognitif siswa sebelum pembelajaran pada materi sistem pernapasan manusia di kelas kontrol diperoleh nilai rata-rata 41,00 dengan kategori "Rendah" dan setelah pembelajaran dengan menerapkan pembelajaran konvensional diperoleh nilai rata-rata 64,04 dengan kategori "Sedang".

3. Hasil analisis data posttest antara kelas eksperimen dan kelas kontrol menggunakan program SPSS Statistics 20 menunjukkan bahwa nilai sig $<\alpha(0,000<0,05)$, maka keputusan Haditerima yaitu Terdapat perbedaan yang signifikan Pengetahuan Metakogitif Siswa antara kelas kontrol dan kelas eksperimen pada Materi Sistem Pernapasan Manusia Kelas VIII Sekolah Menengah Pertama Negeri 6 Satu Atap Sintang.

4. Respon siswa setelah proses pembelajaran dengan menggunakan model pembelajaran Reading Questioning Answering(RQA) pada materi sistem pernapasan adalah $88,20 \%$ dengan kategori "SangatKuat".

\section{REFERENSI}

Amin, A M dan Corebima, A.D. (2016). Analisis Persepsi Dosen Terhadap Strategi Pembelajaran Rading Questioning Answering (RQA) dan Argument Driven Inquery (ADI) Pada Program Studi Pendidikan Biologi di Kota Makassar.

Brasilita, Yuli, dkk. (2013). Pengaruh Model Pembelajaran SIMAS ERIC pada Jenis Kelamin Berbeda terhadap Keterampilan Metagoknitif dan Hasil Belajar Kognitif Siswa di SMAN 6 Malang. Universitas Negeri Malang.

Fauzi, A. (2013). Pengaruh Kemampuan Akademik Terhadap Keterampilan Metakognif, Hasil Belajar Biologi, dan Retensi Siswa Kelas X dengan Penerapan Strategi Pembelajaran Cooperative Script di Malang. Skripsi tidak diterbitkan. Malang: Universitas Negeri Malang.

Haerullah, A dan Usman, F H. (2013). Pengaruh Penerapan Model RQA Terhadap Pengetahuan Metakognitif Siswa Kelas XI IPA SMA Negeri 2 Kota Ternate. Jurnal BIOedukasi. 2(1). ISSN. 2301-4678.

Hasanuddin. (2012). Implementasi Pembelajaran RQA di Padu TPS Melaui Lissen Study Terhadap Hasil Belajar Siswa. Jurnal Ilmiah Pendidikan Biologi, Biologi Edukasi. $4(1)$.

Kemendikbud. (2003). UU Nomor 20 Tahun 2003 Tentang Sistem Pendidikan Nasional. Jakarta: Kementerian Pendidikan dan Kebudayaan.

Pertiwi P dan Sugiyanto.( 2006). Efektivitas Permainan Konstruktif-Aktif untuk Meningkatkan Kemampuan Membaca Siswa Kelas 2 Sekolah Dasar. Jurnal Psikologi. 34(2). ISSN. 0215-8884. 